\title{
ENHANCE Learning Model: A Case Study in Moving the Learner from Novice to Proficient
}

\author{
Dr. Elgloria Harrison ${ }^{1}$, Dr. Morris Thomas ${ }^{2}$ \\ The University of the District of Columbia, Washington, DC, USA \\ morris.thomas@udc.edu
}

\begin{abstract}
The ENHANCE Learning Model (ELM) is a theoretical framework designed to measure how blended course design impact the learning experience of undergraduate learners. In order to test the utility of this model, longitudinal data had been captured in a general education capstone course that provided rich context of course activities that was juxtaposed against each variable of the ELM. The evaluation of this learning model was to determine its predictability of the learners' progress and success in this course and whether it moved the learnerfrom anovice learner to a proficient learner as it pertained to thecourse's content. Additionally, it was expected that the research gathered from the data used to inform the ELM would also provide guidance as to salient characteristics of a high-impact course design. The knowledge learned from this evaluation would support replication of future totally online and/or blendedhigh-impact course designs.
\end{abstract}

Keywords: high-impact; community-inquiry; course design

\section{INTRODUCTION}

The purpose of this paper illustrated principles of self-determined learning in undergraduate capstone courses that embeds community inquiry as the cornerstone to a blended course design. The capstone course discussed employed the ENHANCE learning model. The ENHANCE learning model (ELM) served as the theoretical framework to measure how the blended course design impacted the learning experiences of the undergraduate learners in this study (Thomas, 2016). Moreover, this study discussed how the ENHANCE Learning Model informed High-Impact Course Design.

The ELM is focused on linking the emotional and cognitive aspects needed to positively impact the learning environment and the learners' experience. In course design it is easy for instructors to complicate the course for themselves and for the learners. Each letter in ENHANCE represents a word (Engage Navigate Highlight Assessment Network Connect Edutain) to create a dynamic acronym that encourages thoughtful preparation in designing a course conducive for learning (Figure 1).

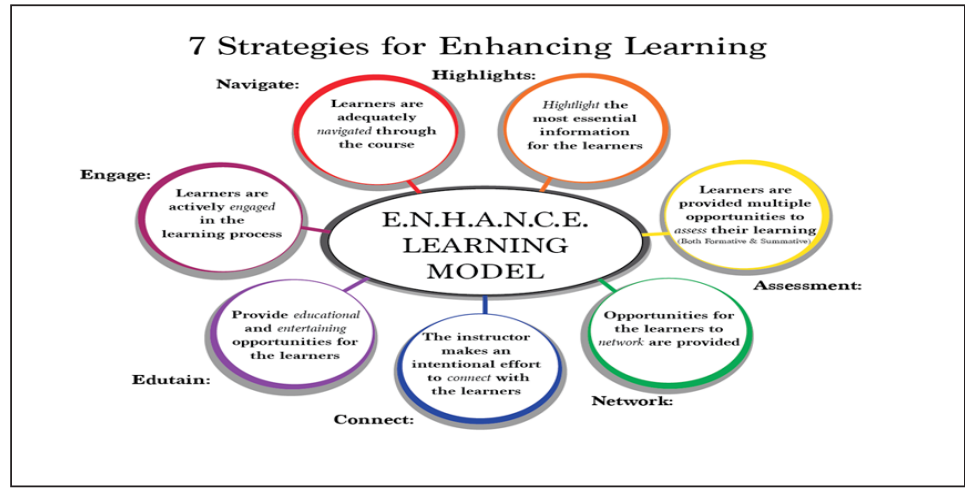

Fig1 
- Engage- It is important to think of ways to engage and involve the learners in the learning process. This does not have to be difficult, and it can be achieved through activities that the learners can perform to make them become a part of the learning experience.

- Navigate- Instructors should ensure that the course is well designed and easy to navigate.

- Highlight- The notion of highlighting involves informing learners of what is important as it pertains to the course. This term is also related to the previous term, Navigate. Highlighting not only involves placing emphasis on what the learners should pay attention to at any particular moment in the course, but it also encompasses the notion that the course cannot and should not cover any and everything involving a particular subject.

- Assessment-Assessment should be ongoing and include both formal and informal assessmentopportunities to provide learners with accurate gauges of their performance in courses.

- Network- Network involves providing opportunities for the learners to learn with whom they are studying; after all, it is very likely that these learners will transition from classmates into colleagues. The relationships that are built into these settings can be lasting but also have a positive impact on the learning that takes place (Rovai, 2002).

- Connect- Connect is similar to network, but in this context it is referring to the instructor connecting to the learners. Learners are more likely to maximize their learning experiences when they perceive a deeper connection to their instructors (Thomas et. al. \& Maki \& Maki, 2007).

- Edutain-Edutain is the combination of the words educate and entertain. This term is pretty self-explanatory; it simply involves the act of learning through methods that both educate and entertain.

Research in neuroscience and the physiology of learning demonstrates the strong link between emotion and cognition; little real learning occurs in the absence of the strong, positive emotions engendered by deep engagement, motivation, interest, and caring (Zull, 2011). The notion of environmental dynamics speaks to the circumstances or conditions that surround the social, intellectual, or moral forces that produce activity and change in a given place (Thomas, Hilton \& Ingram, 2015). Moreover, it is extremely important to consider that learners have varied needs, and these learning environments should be able to accommodate and serve the broadest learner spectrum (Hurtado, Cuellar, \& Guillermo-Wann, 2012). Furthermore, building community is important because several studies suggest that when learners experience learning environments where they feel a sense of belonging; they internalize higher adjustment and satisfaction values with those institutions and are more likely to persist to graduation (Schwitzer, Griffin, Ancis, \& Thomas, 1999).

\section{REVIEW OF LITERATURE}

\section{Teaching and learning in higher education}

Nilson (2010) asserts that some of the most common teaching methods are "lecture, interactive lecture, recitation, directed discussions, writing/speaking exercises, classroom assessment techniques, group work/learning, learner-peer feedback, just-in-time teaching, case method, inquiry-based or guided, problem-based learning, project-based learning, role plays and simulations, service-learning with reflections, and fieldwork/clinical" (p. 107). These methods are meant to help educators reach the specific learning goals. Teaching methods are not meant to be concrete additions to the learning process; they must be intertwined with instructor reflection and revision.

\section{The online learning environment}

Digitally enhanced course designs have gained popularity along with the increase use in online delivery methods. Allen and Seaman (2007) reported that $20 \%$ of all US students were enrolled in a least one online 
course in fall 2006 and the use of the online learning format is expected to increase in usage in the near and long term future of higher education. Bolliger\&Wasilik (2009) indicated the advantage of online learning is the ability to attract more students (traditional and non-traditional), improved graduation rates, and an intentional reach to a broader audience. Just as there are compelling reasons to adopt online learning, there are equally as many barriers that hinder adoption. These are lack of student discipline, lack of faculty acceptance, cost associated with development, and delivery of an online learning system (Bollinger \&Wasilki, 2009). While these barriers are many, institutions are finding good reasons to launch institutional online learning platforms and are claiming success as measured by increased enrollment.

\section{Blended-learning}

In the online environment course design holds the key to any successful e-learning platform. The same can be said for designing a face-to-face or blended course. Course design is everything. E-learning and online learning is used interchangeably throughout this paper. Blended learning is being recognized as a growing teaching tool and has been used in teaching public health, dental, and pharmacy students where the subject matter is complex, requires a lot of hands-on practice, and there is limited time in the classroom to practice these skills (McLaughlin et.al, 2015;Kiviniemi, 2014; Rosenbaum, et al., 2012). Blended learning is a combination of faceto-face with strategic use of online technology. Blended learning could be the way forward to achieve actual student learning outcomes and improved student satisfaction (Lopez-Perez, 2011).

According to Garrison and Kanuka (2004) blended learning is the integration of face-to-face with online learning experiences (p.96). These authors suggest that blended learning requires a fundamental re-design of the teaching and learning dynamics (Garrison and Kanuka, 2004). Inherent in this concept is the ability to facilitate a community of inquiry that stimulates open dialogue, critical debate, negotiation, and agreement that may otherwise not be achievable in a face-to-face classroom setting (Garrison and Kanuka, 2004, p. 97). Further, blended learning requires three elements: cognitive, social, and teaching presence to which achieving higher level of learning is maintained (Garrison and Kanuka, 2004, p.97).

\section{Heutagogy}

In line with blended learning, is the principle of heutagogy, which is the study of self-determined learning (Hase, 2009; Hase\& Kenya, 2003). There is no mistaking, that much of what people learn is not through formal education, in fact most things are acquired through informal channels, such as learning on the job, asking other how to do something, or simply observing. In fact, Hase (2009) suggests that learning occurs when the learner is ready to learn rather than when the teacher expects or intends learning to occur (p.44). Hase (2009), further suggest that it is the experiences outside of the classroom that prompts the neuro-pathways in the brain to suddenly connect. These experiences are linked to the emotion of knowing that undergirds this interconnectedness (Hase, 2009, p. 44).

Northcotte and Boddy (2014) provided an example of heutagogy in action, when they observed staff that was learning to teach online actually learned (p. 735). These authors set about to develop an online resource called Moddle's Little Helper (MLH) as a resource to help novice and experience online teachers. It was only through the iterative process and continuous user feedbacks were they able to bring the resource to the implementation phase. Interestingly, they learned that the concept of heutagogy incorporated emotions into the learning process, which confirmed Hase's research that students learn when they are ready (p.736). These authors and others believe that heutagogy prepares students for self-determined lifelong learning (Northcotte and Boddy, 2014, p. 737). 


\section{ENHANCE Learning Model: A Case Study in Moving the Learner from Novice to Proficient}

\section{Mentor/mentee relationship}

Scientific research exists describing the value of mentor/mentee relationship especially in the natural sciences such as biology, chemistry, and physics (Linn, et al. 2015). These authors and others suggest that students who engaged in these structural mentoring relationships tend to do better than students who do not (Linn, et al., 2015). It is suggested that mentoring promotes persistence, leads to higher order thinking, improved communication skills in the natural sciences and other subjects, and perhaps lead to a satisfying career (Linn, et al., 2015).

While most mentoring relationships are geared toward the in-laboratory experiences, there is much to consider in course designs that are geared toward a virtual online experience and/or blended experiences. Crisp and Cruz (2009) reviewed the mentoring literature of college students from 1990 through 2007 to determined four components that are critical to a successful mentor/mentee relationship:1) psychological and emotional support, 2) support for setting goals and choosing career paths, 3) academic subject knowledge support, and 4) specification of a role model (p. 538). Linking good mentoring to enhanced course designs can lead to effective academic practices that foster improved student satisfaction throughout the educational experience.

\section{Methodology}

The Frontier Capstone Course IGED 391/392 was selected as the single case study to examine factors that enhanced learning strategies in undergraduate who were juniors and seniors in the last semester of their general education program. While the student may have been in their last general education course, not necessarily did this mean the student was at the point of graduation. The historical perspective of this class will be described later in this paper. This single case study method was selected because it allowed for a longitudinal review of both qualitative and quantitative course data. Collection of the data was in the form of faculty's observations, course assessment, student assessment, and review of archival data collected in this course over a period of four years from fall 2013 through fall 2016. In this instance the course instructor is the primary instrument for data collection and observations, which adds to the richness of the case that would otherwise not be available to outsiders.

\section{Case Study}

Creswell (2014) and Patton (2003) suggest that case studies are designs of inquiry found in many fields (p. 13). Creswell (2014) further suggests that cases study research is in-depth analysis of programs, events, activities, or processes (p. 14). In line with Creswell's description, this case research is an in-depth analysis of processes and/or strategies used in the classroom to engage students in self-reflective learning. Merriam $(2002,1995)$ and Yin (2009) further suggests that a single case study presented from a holistic perspective can provide a unique understanding of the situation and its meaning for those involved (p. xii).

Butvilas and Zygmantas (2011), Yin (2009), and Merriam (2002) agreed that qualitative studies are interpretative studies and that case study design is flexible enough to allow any number of research topics to fit within it. In addition, Merriam (2002) suggested that the use of a variety of sources strengthen the validity and reliability of qualitative research. This research employs the use of multiple sources of course documents that highlights movement of students through the learning process from the position of novice to that of proficient and engaged learner.

To validate further the use of this case study methodology,it is tested employingthe ENHANCE theoretical framework a means of evaluating the course data and learning outcomes. Yin (2009) suggested that an established theory is a critical component of case study development because this provides a "sufficient blueprint for the study" (pp. 35-36). Merriam (1995) pointed out that, when a subject is studied over time, it is a historical case study. This longitudinal approach provided a rich context of the events as they evolve. Understanding the historical perspective is important to understanding what factors enabled learner to become capable and competent graduates in their chosen field. 


\section{Results/data analysis}

The Frontier Capstone course was a face to face course that utilized enhanced online technology in fall 2013. This course was the culminating course in the student's general education journey. As a seasoned instructor, with a background in the sciences and communication, it was an opportunity to introduce sustainability as a concept to the student body at the university. The capstone course comprise students from all disciplines across the university and with few exceptions, every student has to take the capstone course. A typical class averages 28 to 30 students each semester. Since the fall of 2013, there have been at least 4 sections of this course offered each fall and spring semester. The Frontier Capstone course on Sustainability Literacy gained in popularity at the university and was aligned to the university land-grant college, which exemplified the land-grant mission of providing academic and non-academic courses to students and the residents of the District of Columbia. As a member of the college, it was an opportunity to share with students the importance of applied research and sustainability was a way of introducing this concept on a broader scale.

The Frontier Capstone course is an interdisciplinary course marked by course identifier IGED 391/392, and was designed as a seminarwith an emphasis on applied research and hands-on in the community activities. As the instructor, with a keen interest in urban sustainability, this course provided an opportunity to research this topic in more depth and one solution was to introduce urban sustainability as the broad overarching theme, with multiple sub-themes that would be explored by students as group projects. As the syllabus was being developed, five themes were chosen: climate change, food safety, food security, water security, and health and wellness. Other themes were added depending on the number of students in the course.

These five themes lend themselves to a group of 5 students and if other themes were added, they included renewable energy, food justice, environmental justices, and transportation. Each of these themes was relevant to urban sustainability and linked to day-to-day local sustainability issues. The course was developed with $50 \%$ of the work done by the individual student and $50 \%$ of the work done in the group. While most students did not like the idea of group work, not to mention $50 \%$; most interpreted the requirement as a must to be successful in this course. This next section will highlight some of the more salient findings from student course work from the spring 2016 and fall 2016. This section will begin with instructor's observations and reflections followed by illustrations of course findings that highlighted ENHANCE in action.

\section{Instructor's observations and reflections}

In teaching the last 10 years, it has become apparent the amount of coursework students complete outside the classroom has decreased; the frontier capstone course gave a rare opportunity to provide outside reading, group activities, and discussion board forums that related directly to the work that was discussed in the classroom. It was not apparent to me as an instructor that blended learning was becoming a reality in this frontier capstone course and the results were inextricably linked to achieving the learning outcomes. In fact, it became more evident as I reflected on my own thinking about this course, that I was slowly and willingly giving more control to the students as I moved from the stage to the sidelines. It did not happen all at once; and in some instances, students did not always appreciate being in control of their learning. Nonetheless, my own sense of joy in teaching seemed to heighten as I observed the changes in the student's ability to move the learning needle from novice to proficiency. It is fair to say that eighty percent of the class in both the spring and fall semester moved the learning needle from novice to proficiency, while the remaining twenty percent moved the learning needle from novice to competency. This paper defines novice, an assignment that demonstrates basic understanding, competent, an assignment that demonstrates good understanding, and proficient, an assignment that demonstrates thorough understanding.

Often as a teacher, we are quite satisfied if the majority of our students acquire a passing grade, we interpret this as success; but we often move about preparing for the next course with little opportunity to really reflect on what really happened in the previous course. Rarely, do we ask what assignment or activity really made the 
ENHANCE Learning Model: A Case Study in Moving the Learner from Novice to Proficient

difference that caused students to do well. On the other hand, if students do poorly, sometimes as teachers we lay blame that students come poorly prepared or some other negative reasons that students were not successful in our class.

In an era where assessment has taken over our academic lives, it was important to understand this phenomenon and really asked the question "what am I doing right in this course?" This question was very important to me as mid-season instructor, that I have not reached the burnout period in my teaching career and perhaps the answer may help me help other teachers keep the teaching fire going. If what I did right, can I replicate it, can I show others, what was it? The questions and others were basic questions; but in a course of 28 to 30 students who come from all walks of life, my goal was to influence their abilities to be responsible for their own learning, to ask bold questions, to challenge the status quo, and to be happy with learning something new. Yes, to be happy to learn something new.

While my reflections were my reflections, the scientist in me said, your actions must be quantified. In my effort to measure what I believe is course success, the ENHANCE learning model was introduced to the university community. The ENHANCE learning model was developed to help instructors design online and/or blended courses that are meaningful and satisfying to teachers and students alike in the online environment. ENHANCE offers seven strategies: E (Engage), N (Navigate), H (Highlight), A (Assessment), N (Network), C (Connect), E (Edutain) and while this framework was developed to capture the attention of students in the online environment. In view of the strategies, we juxtaposed the findings of the course document to the seven strategies to determine whether this model would actual provide measurements of this course success.

\section{E.N.H.A.N.C.E LEARNing Model ANALYZED}

\begin{tabular}{|c|c|c|}
\hline $\begin{array}{l}\text { Key Elements of } \\
\text { ENHANCE }\end{array}$ & Evidence of the Key Element & Was it Measurable \\
\hline E-Engage & $\begin{array}{l}\text { Community engage activities -SPRING } 2016 \\
\text { On Thursday } 31 \text { March } 2016 \text { our group was invited by XXXXXXX } \\
\text { to attend a community meeting at Westminster Church in SW } \\
\text { Washington D.C. The purpose of the meeting was for residents } \\
\text { of that local Buzzard Point community and people outside the } \\
\text { community to come together for the common cause of discuss- } \\
\text { ing environmental threats to that community. One of the most } \\
\text { crucial threats that the people were concerned with is the con- } \\
\text { structing of a new soccer stadium in that community. They were } \\
\text { so concerned due to the health threats that it poses to the people } \\
\text { in that particular Buzzer Point area. One of the most important } \\
\text { health threats that they spoke of was air quality. Consequently, a } \\
\text { citizen of the area spoke of how the cancer rates in that area were } \\
\text { through the roof, so maybe there is a correlation to the cancer } \\
\text { rate and the air quality. This meeting for us was very enlighten- } \\
\text { ing, because the term of environmental justice was no longer just } \\
\text { a term. It was real, and we saw and listened to real people who } \\
\text { were emotional about the health of their environment. We were } \\
\text { afforded the opportunity to witness the stories and struggles of } \\
\text { real people who were going through the same thing that we have } \\
\text { been researching, and I believe that process was very essential to } \\
\text { our research }\end{array}$ & $\begin{array}{l}\text { Five members of this } \\
\text { group attended this } \\
\text { environmental justice } \\
\text { communitymeeting and } \\
\text { were actively involved } \\
\text { in the question and } \\
\text { answer session }\end{array}$ \\
\hline
\end{tabular}


ENHANCE Learning Model: A Case Study in Moving the Learner from Novice to Proficient

\begin{tabular}{|c|c|c|}
\hline & $\begin{array}{l}\text { Community engage activities -FALL } 2016 \\
\text { On Saturday 12Nov 2016, The research started by our group } \\
\text { being offered the opportunity to work alongside XXXXXXX to } \\
\text { collect our data on D.C. Ward } 6 \text { Natural Resources. XXXXXXX } \\
\text { was kind enough to go over the proposal with us. The proposal } \\
\text { helped us be prepared for doing the survey. XXXXXX explained } \\
\text { to us that the survey would be performed in Ward } 6 \text {, and that } \\
\text { the whole purpose of the survey was to gain an understand- } \\
\text { ing on the public's perspective on Natural Resources and cli- } \\
\text { mate change. The proposal consisted of some of the factors that } \\
\text { would be taken into consideration when doing the research. } \\
\text { Therefore, we had to consider demographics, average income, } \\
\text { racial makeup, and social economics. } \\
\text { Most group members were present for the survey on a Satur- } \\
\text { day morning in Ward } 6 \text { (Buzzards Point). We each performed } \\
\text { the same role, and that was to take the Ipad's with the survey's } \\
\text { on them around Buzzard's Point location. We each dispersed } \\
\text { around the area and started asking the locals whether they } \\
\text { would like to answer the questions to our survey. The goal was } \\
\text { to at least ask } 5 \text { people each and we all got around about } 4 \text { ex- } \\
\text { cept IM who managed to get } 5 \text { surveys'. As a result of this, we } \\
\text { managed to get data from the assessment and with the help } \\
\text { of XXXXXX we were able to have the data at our accessibil- } \\
\text { ity on an excel spreadsheet. From this we did some pie charts } \\
\text { and bar charts on the results making it a lot clearer to us the } \\
\text { responses. }\end{array}$ & $\begin{array}{l}\text { Five members of this } \\
\text { group collect surveys } \\
\text { on a Saturday morning } \\
\text { in Ward 6, each member } \\
\text { approached the public } \\
\text { regarding the idea of } \\
\text { climate change and } \\
\text { natural resources in this } \\
\text { particular Ward of DC. } \\
\text { This activity was their } \\
\text { service learning project } \\
\text { where the group } \\
\text { members had to identify } \\
\text { an urban problem and } \\
\text { go into the community } \\
\text { to investigate. } \\
\text { Result of the service } \\
\text { learning activity } \\
\text { assessed each studentas } \\
\text { competent in engaging } \\
\text { the community. }\end{array}$ \\
\hline $\mathrm{N}$-Navigate & $\begin{array}{l}\text { Blackboard Discussion Forum---required the student to answer } \\
\text { four questions and respond to two other students. } \\
\text { 1. What is your understanding of the concept of climate change } \\
\text { and the urban heat island effect? } \\
\text { 2. Describe changes in weather pattern variability as a factor on } \\
\text { their health and wellbeing? } \\
\text { 3. How does climate change impact food security? } \\
\text { 4. How does climate change impact water security? } \\
\text { In this discussion you must provide a thorough answer to } \\
\text { each of the questions. The total word count for all questions } \\
\text { should be } 250 \text { to } 300 \text { words. You must respond to two other } \\
\text { students and this word count should be } 50 \text { to } 100 \text { words. You } \\
\text { may respond to more than two students; but you must respond } \\
\text { to at least two students. }\end{array}$ & $\begin{array}{l}22 \text { of } 28 \text { students } \\
\text { participated in this } \\
\text { forum for a response } \\
\text { rate of } 79 \% \text {; however } \\
16 \text { of the } 28 \text { received } \\
\text { all } 100 \text { points while } 6 \\
\text { students received } 50 \\
\text { points moving them } \\
\text { to the position of } \\
\text { proficiency. } \\
16 \text { of } 28 \text { students could } \\
\text { navigate this site and } \\
\text { perform the function as } \\
\text { instructed and therefore } \\
\text { received the full score. }\end{array}$ \\
\hline
\end{tabular}


ENHANCE Learning Model: A Case Study in Moving the Learner from Novice to Proficient

\begin{tabular}{|c|c|c|}
\hline H-Highlight & $\begin{array}{l}\text { Developing a one page scheduler was the key to highlighting } \\
\text { major assignments. } \\
\text { This was an effective mechanism in assuring student they could } \\
\text { be successful in the course. } \\
\text { Students visualized all the major assignments and their } \\
\text { respective due dates. } \\
\text { This was an important development as students become } \\
\text { overwhelmed with trying to fit too many assignments in } \\
\text { their schedule. Most students found this re-assuring that } \\
\text { the assignments were developed to allow them to miss an } \\
\text { assignment without significantly impacting their success in the } \\
\text { course. }\end{array}$ & $\begin{array}{l}83 \% \text { of students opt } \\
\text { to not complete one } \\
\text { assignment; recognizing } \\
\text { that missing the one } \\
\text { assignment did not } \\
\text { impact their desired } \\
\text { grade for the course. }\end{array}$ \\
\hline A-Assessment & $\begin{array}{l}\text { Rubrics were used in major assignments to include } \\
\text { Oral presentations, writing assignments and discussion board } \\
\text { forum. Rubrics appear to help the students understand how } \\
\text { they were being assessed and what each could do to move to } \\
\text { the next level. Many opportunities were afforded the students } \\
\text { to master the learning outcomes }\end{array}$ & $\begin{array}{l}80 \% \text { of students } \\
\text { moved from Novice to } \\
\text { proficiency } \\
20 \% \text { of students } \\
\text { moved from Novice to } \\
\text { Competent }\end{array}$ \\
\hline $\mathrm{N}$-Network & $\begin{array}{l}\text { Network throughout the UDC Community } \\
\text { An open discussion during class time within the members of this } \\
\text { group, raised questions in relation to how the lifestyle habits of } \\
\text { students of UDC compared to information we were to gather } \\
\text { from the preliminary research. Subsequent to all fundamental } \\
\text { assignments that ultimately provided the framework for } \\
\text { the final paper, each researcher promptly completed their } \\
\text { portion of their literature review/annotated bibliographies } \\
\text { and volunteered to assign themselves a portion of the service } \\
\text { learning proposal. Everyone participated in the brainstorming } \\
\text { process of how obesity is adversely affected by physiological/ } \\
\text { environmental factors and methods of prevention. AP created } \\
\text { the visual representation for the concept map that ultimately } \\
\text { solidified our study question. The proposal of this study was } \\
\text { a reaction to the findings through the annotated bibliography } \\
\text { and literature review. The individuals in this research group } \\
\text { actively participated and interacted on a weekly basis with } \\
\text { constant communication via text messages in an extensive } \\
\text { group chat, e-mail threads, and met during our time off from } \\
\text { IGED } 391 / 392 \text { to give the data results to BR for analysis and to } \\
\text { produce graphs for the data. } \\
\text { Participants. Prior to the research study, the survey was approved } \\
\text { byXXXXXXvia email. Theparticipants of this study werestudents } \\
\text { enrolled in the University of the District of Columbia (UDC). The } \\
\text { ninety ( } 90 \text { ) UDC students volunteered to be surveyed regarding their } \\
\text { health and wellness behaviors affecting their lifestyle choices. }\end{array}$ & $\begin{array}{l}\text { This group developed } \\
\text { their research question, } \\
\text { planned their hypoth- } \\
\text { esis and used their own } \\
\text { classes as participants } \\
\text { to determine the suc- } \\
\text { cess or failure of the } \\
\text { project. } \\
\text { Members of this group } \\
\text { moved the learning } \\
\text { need to the position of } \\
\text { proficiency. }\end{array}$ \\
\hline
\end{tabular}


ENHANCE Learning Model: A Case Study in Moving the Learner from Novice to Proficient

\begin{tabular}{|c|c|c|}
\hline & $\begin{array}{l}\text { The survey included thirteen (13) questions about their age, } \\
\text { gender, height, current attitude toward their self-image, current } \\
\text { activity level, hunger levels throughout their day, daily water } \\
\text { intake, average hours of sleep, history of family obesity, and the } \\
\text { occurrence of their healthy food choices between weekly meal } \\
\text { prepping and buying fast food. } \\
\text { Each researcher distributed their surveys to their classmates } \\
\text { in UDC. The following is where the convenience sampling was } \\
\text { conducted to eliminate the probability of participant overlap: } \\
\text { AP - Classroom Management; BR - Journal Club; DC - History \& } \\
\text { Philosophy of Childhood Education; EA - Political Ideology; JD - } \\
\text { Neuroscience Lab; and PR - Business Policy \& Strategy. } \\
\text { XXXXXXX held a teleconference call on November 22, 2016, } \\
\text { gauging the status of the assignment. She helped clarify our } \\
\text { questions regarding formatting and gave the approval to continue } \\
\text { on with the assignment. }\end{array}$ & \\
\hline C-Connect & $\begin{array}{l}\text { Group members connect it's a beautiful thing } \\
\text { Doing this assignment of renewable energy it was a very } \\
\text { interesting one. In this world there are plenty of ways we } \\
\text { can harness the energy we need to function for everyday } \\
\text { life. We decided to focus on four of the many options such as } \\
\text { hydroelectric (water), Geothermal, Wind, and solar. As it was } \\
\text { four members in our group we were able to conduct our own } \\
\text { research for each individual source of energy discussed above. } \\
\text { Hydroelectric is used when we harness the energy from the } \\
\text { source of water. It could be water from the ocean and or a river, } \\
\text { which is more common now a day. We also notice this type with } \\
\text { dams or levees. Geothermal energy is energy used form the } \\
\text { core temperature of the earth. It is most commonly found on } \\
\text { the west coast of the United States. A quick fun fact is that the } \\
\text { new student center here at UDC has used geothermal energy to } \\
\text { be built. The drilling for it took place on the field located off of } \\
\text { Van Ness Street. Wind energy is a unique one because it has one } \\
\text { source, Wind Turbine. The last and final source of energy we } \\
\text { focused on was solar energy. Solar energy is energy used from } \\
\text { the Sun and it is harnessed through solar panels. } \\
\text { We decided that the most effective way to complete this }\end{array}$ & $\begin{array}{l}\text { This result of their } \\
\text { findings for solar panels } \\
\text { usage was surprising } \\
\text { and their interpretation } \\
\text { of their finding very well } \\
\text { developed. Members of } \\
\text { this group moved the } \\
\text { learning needle to the } \\
\text { position of proficiency. }\end{array}$ \\
\hline & $\begin{array}{l}\text { assignment is to break off and do individual research of our } \\
\text { assigned source of energy. While away from each other and } \\
\text { doing we made sure that we met in the library once a week to } \\
\text { go over our progress as well as to discuss new findings that } \\
\text { we have found for this research. LL was responsible for doing } \\
\text { research for wind energy, JZ was responsible for doing research } \\
\text { on geothermal energy, VT was responsible for doing research } \\
\text { hydroelectric energy and AF was responsible for doing research }\end{array}$ & \\
\hline
\end{tabular}


ENHANCE Learning Model: A Case Study in Moving the Learner from Novice to Proficient

\begin{tabular}{|c|c|c|}
\hline & $\begin{array}{l}\text { on solar energy. After discussing it as a whole group we } \\
\text { decided that it's best to focus on solar energy. The reason } \\
\text { why we stuck with this is because of the simple fact that } \\
\text { we have are able to conduct research much easier.it made } \\
\text { sense to do this because in this northeast region we are } \\
\text { most likely to find solar energy. }\end{array}$ & \\
\hline E-Edutain & $\begin{array}{l}\text { Humor is a good sign that the professor is confident in } \\
\text { her knowledge of the subject matter and the student } \\
\text { respond in kind to the humor. The most compelling } \\
\text { evidence of students } \\
\text { Attendance centered on the fact that I knew their first } \\
\text { and last name by the second day of class. This was a } \\
\text { powerful finding. }\end{array}$ & $\begin{array}{l}\text { Measured by attendance. } \\
\text { Attendance roster showed } \\
\text { consistently that } 90 \% \text { of stu- } \\
\text { dents attended classes week- } \\
\text { ly and } 100 \% \text { showed up on } \\
\text { Blackboard weekly. }\end{array}$ \\
\hline
\end{tabular}

\section{CONCLUSION}

This study sought to discuss instructional approaches to develop and inform high-impact course design. The authors found that in order to move the learner needle from novice to proficient teaching methods should be discovered, deployed, and frequently revised to elicit learning (Ambrose, Bridges, DiPietro, Lovett \& Norman, 2013). Inherent with the heutagogy principles is the idea of self-reflection and metacognition, where the learner understands his or her own learning process (Blaschke and Hase, 2016, p.27). Moving the needle from novice to proficient students involved creating an intentional learning experience using ELM, built on learner recognition.

The authors found that this moved the instructor to the role of facilitator and away from the pedagogical principles established in the educational academy many years ago. Most college and universities are diverse institutions with respect to both traditional and non-traditional students. When courses are designed in ways that encourage reflective critical thinking or moves the student to a higher order of learning, it may become the single biggest leap in improving learning in higher education (Garrison, 2004). Blended learning along with heutagogical principles (the study of self-determined learning) may be the undeniable secret to moving the needle from novice to proficient student performance, which was the desired learning outcome.

The influxes of the non-traditional students (those over 18) have come to disrupt the educational establishment; these students are now consumers of education and no longer innocent bystanders. These students are less patient with the current classroom arrangements which can translate into poor attendance, failure to attend, course withdrawal, and perhaps failure to persist toward graduation. It is this context that the need to design courses that impact the success of these students are evident and academic developers in higher education have an opportunity to impact the future of undergraduates in acquiring skills that benefit them long after graduation. We found that purposefully designing courses to include critical strategies posited by the ELM proved beneficial for the learners.

\section{REFERENCES}

Allen, I.E., Seaman, J. (2007). Online nation: Five years of growth in online learning. Needham, MA; Sloan-C. http://www.sloan- consortium.org/publications/survey/pdf/online_nation.pdf

Ambrose, S., Bridges, M. W., DiPietro, M., Lovett, M. C., \& Norman, M. K. (2010). How learning works: seven research-based principles for smart teaching. San Francisco, CA: Jossey-Bass.

Blaschke, L.M., Hase, S. (2016). In B.Gros et al. (eds.) The future of ubiquitous learning. 
ENHANCE Learning Model: A Case Study in Moving the Learner from Novice to Proficient

Lecture Notes in Educational Technology, Doi: 10.1007/978-3-662-47724-3_2

Bollinger, D.U., Wasilik, O. (2009). Factors influencing faculty satisfaction with online teaching and learning in higher education, 30 (1), 103-116. Doi: 10.1080/01587910902845949

Butvilas, T., \&Zygmantas, J. (2011). An ethnographic casestudyin educational research.ActaPaedagogicaVilnensia, 27. Retrieved from http://www.ceeol.com

Creswell, J.W. (2014). Research Design Qualitative and Quantitative and Mix Methods $4^{\text {th }}$ edition. Thousand Oaks, CA: Sage.

Crisp, G., Cruz, I. (2009). Mentoring college students: A critical review of the literature between 1990 and 2007. Research Higher Education 50, 525-545. Doi: 10.1007/s11162-009-9130-2

Garrison, D.R., Kanuka, H. (2004). Blended learning: Uncovering its transformative potential in higher education. Internet and Higher Education. 7, 95-105

Hase, S. (2009). Heutagogy and e-learning in the workplace: Some challenges and opportunities. Impact: Journal of Applied Research in workplace E-learning. 1 (1), 43-52. Doi; 10.5043/impact.13

Hase, S., Kenyon, C. (2003). Heutagogy and developoing capable people and capable workplaces; strategies for dealing with complexity. In Proceeding of the changing face of work and learning conference. Edmonton, AB; University of Alberta.

Hurtado, S., Cuellar, M., \& Guillermo-Wann, C. (2012, April). Quantitative measures of students' sense of validation: Advancing the study of diverse learning environments. Paper presented at the American Educational Research Association annual meeting. Vancouver, B.C., Canada.

Kiviniemi, M.T. (2014). Effects of a blended learning approach on student outcomes in a graduate-level public health course. BMC Medical Education. 14, 47. Doi: 10.1186/1472-6920-14-47

Linn, M.C., Palmer, E., Baranger, A., Gerard, E., Stone, E. (2015). Undergraduate research experiences: Impacts and opportunities. Science. 347 (6222). Doi: 10.1126/science.1261757

Lopez-Perez, M.V., Lopez-Perez, M.C., Rodriquez-Ariza,L. (2011). Blended learning in higher education: Student's perceptions and their relation to outcomes. Computers \& Education. 56, 818-826. Doi: 10.1016/j. compede.2010.10.023

Merriam, S. (1995). Theory to practice. What can you tell from an $\mathrm{N}$ of 1 ? Issues of validity and reliability in qualitative research. PAACE Journal of Lifelong Learning, 4, 51-60. Retrieved from http://www.iup.edu

Merriam, S. (2002). Qualitative research in practice: Examples for discussion and analysis. San Francisco, CA: Jossey-Bass.

McLaughlin, J.E., Gharkholonarehe, N., Khanova, J., Deyo, Z.M., Rodgers, J.E. (2015). The impact of blended learning on student performance in a cardiovascular pharmacotherapy course. American Journal of Pharmacy Education, 79 (2). 24. Doi: 10.5688/ajpe79224

Nilson, L. B. (2010). Teaching at its best: a research-based resource for college instructors. San Francisco, CA: Jossey-Bass.

Northcote, M.T., Boddey, C. (2014). Using the self-determined learning principles of heutagogy to support academic staff who are learning to teach online. Education Conference Papers. Paper 9 http://research. avondale.eduau/edu_conferences/9

Patton, M.Q. (2002). Qualitative research and evaluation methods. Thousand Oaks, CA: Sage. 
ENHANCE Learning Model: A Case Study in Moving the Learner from Novice to Proficient

Rosenbaum, P.E., Mikalsen, O., Lygre, H., Solheim, E., Schjott, J. (2012). A blended learning course design in clinical pharmacology for post-graduate dental students. Open Dental Journal, 6, 182-187. Doi: $10.2174 / 1874210601206010182$

Rovai, A. P. (2002). Development of an instrument to measure classroom community. Internet and Higher Education, 5(3), 197-211.

Scwitzer, A.M., Griffin, O.T., Kancis, J.R., \& Thomas, C.R. (1999). Social adjustment experiences of African American college learners. Journal of Counseling and Development, 77, 189-197.

Thomas, M. (2016). Enhancing Learning in Online Environments. RAIL Review

Thomas, M., Hilton, A.A., \& Ingram, T.(2015, November). Campus environments: their importance and impact. Paper presented at theAssociation for the Study of Higher Education (ASHE) $40^{\text {th }}$ Annual Conference.

Yin, R. K. (2009). Case study research: Design and methods (4th ed.). Thousand Oaks, CA: Sage.

Zull, J. E. (2011). From brain to mind. Sterling, VA: Stylus Publishing.

Citation: Dr. Elgloria Harrison, Dr. Morris Thomas. "ENHANCE Learning Model: A Case Study in Moving the Learner from Novice to Proficient" American Research Journal Of Humanities and Social Sciences, vol 4, no. 1, 2018, pp. 1-12.

Copyright (c) 2018 Dr. Elgloria Harrison, Dr. Morris Thomas. This is an open access article distributed under the Creative Commons Attribution License, which permits unrestricted use, distribution, and reproduction in any medium, provided the original work is properly cited. 